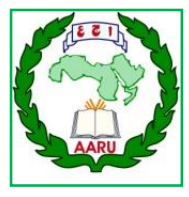

Arab Univ. J. Agric. Sci., Ain Shams Univ., Cairo, Egypt

29(2), 775-786, 2021

Website: http://ajs.journals.ekb.eg

DOI: 10.21608/ajs.2021.74341.1371

\title{
Effect of Fungicide, Salicylic Acid, Henna Powder and Propolis on Silk worm Larvae Infected with Aspergillus spp.
}

\section{Eman A Abd El-Razek ${ }^{1}$, Madiha A Rizk ${ }^{1}$, YEY Abdallah ${ }^{1}$, Khadiga A Abou-Taleb ${ }^{2}$, Sawsan M Abdelmegeed ${ }^{1 *}$}

1- Plant Protection Dept, Fac of Agric, Ain Shams Univ., P.O. Box 68, Hadayek Shoubra 11241, Cairo, Egypt

2- Agricultural Microbiology Dept, Fac, Agric, Ain Shams Univ, P.O. Box 68, Hadayek Shoubra 11241, Cairo, Egypt

* Corresponding author: sawsan_ali@agr.asu.edu.eg

Received 27 April, 2021

Accepted 7 August, 2021

\begin{abstract}
Mulberry silkworm, Bombyx mori L. is infected with many diseases. In this work, two fungi species, Aspergillus fumigatus and Aspergillus flavus, were isolated from the infected $B$. mori larvae during rearing process. The morphological symptoms were the same for both fungi and appeared from newly hatched larvae until moth formation. In larvae, black spots of both fungi species appeared everywhere on the body, then these spotsextended and eventually larvae died, and fragments of the fungus came out from the spots. The only one difference between the two fungi, is that symptoms of A. fumigatus appeared four days earlier than those of A.flavus. Newly hatched larvae were sprayed with spore suspension ( $1 \times 10^{6}$ conidia spores $\left./ \mathrm{ml}\right)$ of A. fumigates and A. flavus separately. One and $12 \mathrm{hrs}$. after inoculation, larvae were sprayed with different concentrations of fungicide (Actamyl), salicylic acid, and henna and propolis powders, in isolation. After words, mortality and survival percentages were calculated and compared to those that occurred in untreated check (larvae were inoculated with A. fumigatus and A. flavus separately without any control treatment). The lowest mortality and highest survival percentage were occurred in larvae treated with
\end{abstract}

salicylic acid at $10 \%$ after $12 \mathrm{hrs}$. from inoculation with A. fumigatus. On the other hand, the lowest mortality and highest survival percentages occurred in larvae treated with the fungicide Actamyl at 6\% and henna at $15 \%$ after 12 hrs. from inoculation with A. flavus.

Keywords: Actamyl, Aspergillus fumigatus, Aspergillus flavus, Survival, Mortality

\section{Introduction}

Mulberry silkworms, B. mori rear in laboratories under controlled conditions since 2900 $\mathrm{BC}$, which made them more sensitive to diseases and weather changes of temperature and humidity more than other insects resulting indirect effects on cocoons production (Doreswamy et al 2004). Therefore, many different diseases attack $B$. mori in such conditions, whether it were hereditary diseases such as Pebrine disease or through secondary infection as in other diseases (Veeranna 1999). Fungal diseases are the most contagious diseases that appear on mulberry silkworms because of the presence of high humidity and lack of bed change and fungal infections such as $A$. fumigatus, A. flavus, A. oryzae and A. niger. (Kawakami, 1982, Kawakami, 1995, Govindan 
and Devaiah, 1995, Shobha et al 2016, Harinatha, 2017). Some materials have been used to prevent and reduce the appearance of fungi such as plant extracts (Saad et al 2019), antibiotics (Mohanta et al 2015), and biological materials and fungicides (Singh et al 2002). The aim of the study is isolation and identification fungal diseases which infected mulberry silk worm, and record the pathological symptoms, and use some natural materials and fungicides to reduce the infected B. mori with Aspergillus spp and to evaluate their impacts on both survival and mortality rates of the mulberry silkworms.

\section{Materials and Methods}

Experiments were conducted on larvae of B. mori in the laboratory of Insect Physiology, department of Plant Protection. Fungal isolation, purification, pathogenicity and identification were conducted at the Agricultural Microbiology and Plant Diseases Departments, Faculty of Agriculture, Ain Shams University, Cairo, Egypt. For rearing, eggs of mulberry silkworm were obtained from the Sericulture Research Unit, Agriculture Research Center, MoA, Giza, Egypt.

All tools used in the mass rearing, as well as the rearing room, were disinfected with formalin (3\%) one week before the beginning of the experiments. The rearing room was supplied with an adequate number of breeding frames each of $200 \times 80 \times 5 \mathrm{~cm}$. Soon after hatching, larvae were supplied with enough fresh and clean mulberry leaves, Morus alba L. The rearing technique was as that described by Krishanaswami (1983), Nour (2009).

\subsection{Samples collection, isolation, and purifi- cation of fungal pathogenic}

During the rearing of the larvae, the fungal pathological symptoms that occurred were observed daily. The fungi infected larvae were collected based on visual examination then confirmed by microscopically examining using light microscope 400x.

The fungal spores presented on larvae surfaces were isolated under aseptic conditions according to the method described by Simmons et al (2000), Johnyet al (2012). Both surfaces of the infected larvae were sterilized with sodium hypochlorite solution $1 \%$ for 2-3 min., then rinsed twice with distilled water and then passed on filter paper (Whatman No. 1) to remove the remaining water. The infected larvae were cut-off into small bits and transferred to Petri dishes containing potato dextrose agar medium (PDA) (Difco Manual, 1998) which composed of $(\mathrm{g} / \mathrm{L})$ : potatoes, 200 , dextrose, 20, agar, 20 and adjusted to $\mathrm{pH}$ 5.0. The plates were incubated at $25 \pm 2^{\circ} \mathrm{C}$ for $3-4$ days. The developing fungi were examined under light microscope (100x and 400x) for confirming that they were purified as a single spore then these colonies were transferred on other PDA plates to get pure cultures. The purified isolated fungus was preserved on agar slant at $5^{\circ} \mathrm{C}$ after incubation at $25 \pm 2^{\circ} \mathrm{C}$ for $3-4$ days and they were used for further investigation.

\subsection{Phenotypic identification of the patho- genic fungi}

The fungal identification was carried out at the botanical clinic, Department of Plant Diseases, Faculty of Agriculture., Ain Shams University. The obtained two fungal isolates (SW1 and SW2) were identified based on morphological appearance under the microscope (shape and color of conidia) and cultural properties according to Barnett and Hunter (1998), Humber (2005).

\subsection{Preparation of spore suspension and standard fungal inoculum}

The tested fungal isolates grown on PDA slants for five days at $28^{\circ} \mathrm{C}$ were used to prepare the spore suspensions by adding $10 \mathrm{ml}$ of autoclaved tap water to each fungal agar slant and gently scraped the surface of the culture with a sterile inoculation loop. The spore suspension from each slant was pooled to obtain the required quantity of spore suspension for inoculation. The concentrated spore suspension was transferred to a conical flask containing distilled water with a drop of tween-80 to keep the conidia dispersed and was thoroughly 

Silkworm Larvae Infected with Aspergillus spp.

shaken for $10 \mathrm{~min}$. The suspension was then filtered through a sterilized filter paper (Whatman No. 1). The obtained spores were counted using. The Neubauer Haemocytometer slide (Cantwell, 1970). The suspension was then prepared at a concentration of $1 \times 10^{6}$ spores $/ \mathrm{ml}$ which was used as a standard inoculum.

\subsection{Pathogenicity testing of the examined fungal strains}

The neonates and newly molted second, third, fourth and fifth instars of B. mori were inoculated, in isolation, by spraying the suspension $\left(1 \times 10^{6}\right.$ conidia spores/ $\left.\mathrm{ml}\right)$ of $A$. fumigatus and A. flavus separately onto the integument of the silkworm with the help of an automizer and larvae treated with distilled water were used as control (untreated). Each treatment was replicated four times and each replicate contained ten larvae. From the day of inoculation to the end of the fifth instar, silkworm larvae were kept under continuous surveillance to examine the symptom changes during the development of fungal and photographs were taken.

\subsection{Control of Aspergillus spp.}

Control experiments were conducted using1970 newly hatched larvae. Larvae were divided into two groups, each group contained 960 larvae in addition to untreated check group which contained 50 larvae. The first group was inoculated topically by spraying suspension ( $1 \times 10^{6}$ conidia spores $/ \mathrm{ml}$ ) of A. fumigatus to the integument of the silkworm with the help of an automizer and was divided into two subgroups, in the first subgroup (480 larvae), the fungus was controlled one hour after inoculation by a fungicide (Actamyl, dimethyl, 4,4'(o-phenylene) bis (3-thioallophanate) (2,4 and $6 \%$ ), and by salicylic acid, henna powder and propolis powder using 5,10 and $15 \%$ from each of them separately in addition to untreated check (larvae infected with the fungus only). In every concentration, three replicates were used with ten larvae in each replicate. All materials were weighed out as per the required quantity and mixed properly with inert kaolin powder.

The second subgroup (480 larvae) received the same treatments but was treated twelve hrs. after inoculation with the fungus. The second group of experiments was inoculated by A. fla$v u s$ and received the control treatments mentioned above.

Larvae were fed with mulberry leaves after 30 minutes of dusting the controlling materials and reared under optimum temperature $\left(28 \pm 1^{\circ} \mathrm{C}\right)$ and relative humidity (85-90\%). Mortality was recorded after four days in $A$. fumigatus and eight days in A. flavus.

\section{Results and Discussions}

\subsection{Phenotypic identification of the patho- genic fungal isolates}

According to the cultural and morphological properties of the fungal isolates, SW1 and SW2, which were subjected to classification, they belonged to the genus Aspergillus. Both isolates showed granular colonies on PDA. The colonies were flat, with radial grooves (Fig 1). Microscopic observation of each fungal isolate indicated erect conidiophores with globose vesicles bearing chains of conidia (Fig 2). As a result, isolates were identified as $A s$ pergillus fumigatus (SW1) and Aspergillus flavus (SW2).

\subsection{Pathological symptoms}

The pathological symptoms were very same in A. fumigatus and A. flavus but the first fungus showed symptoms four days earlier than the second one.

\subsubsection{The first instar larvae}

Newly hatched silkworm larvae that inoculated with Aspergillus fungus died within 48 hours after infection without any external disease symptoms, as the larvae became dry and stuck to mulberry leaves. On dead larvae, mycelial cluster developed quickly and formed conidia after one day (Fig 3 A). 

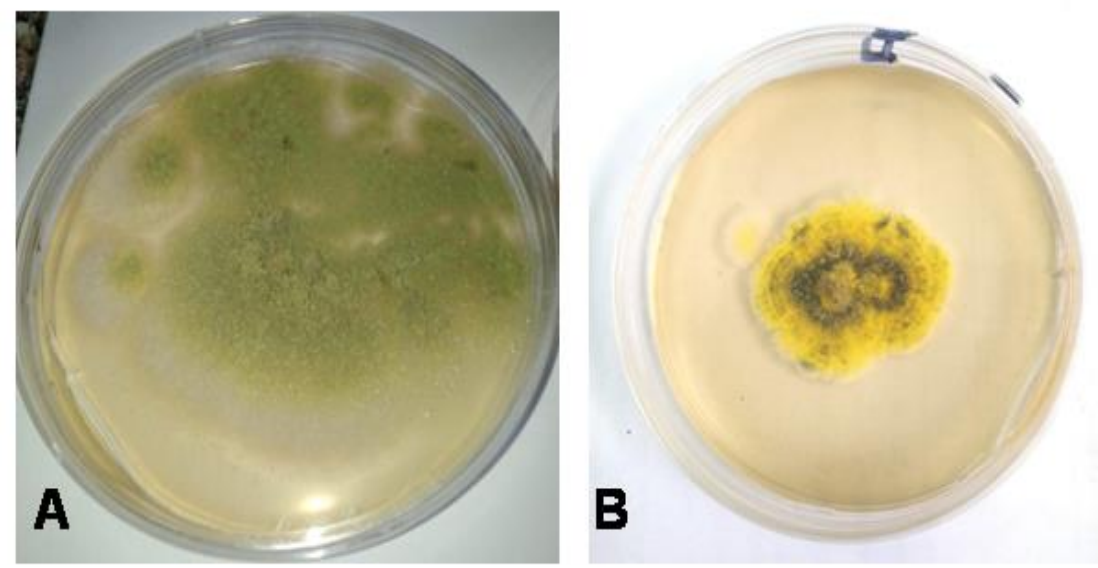

Fig 1. The cultural of fungal isolates (A-SW1 and B-SW2)
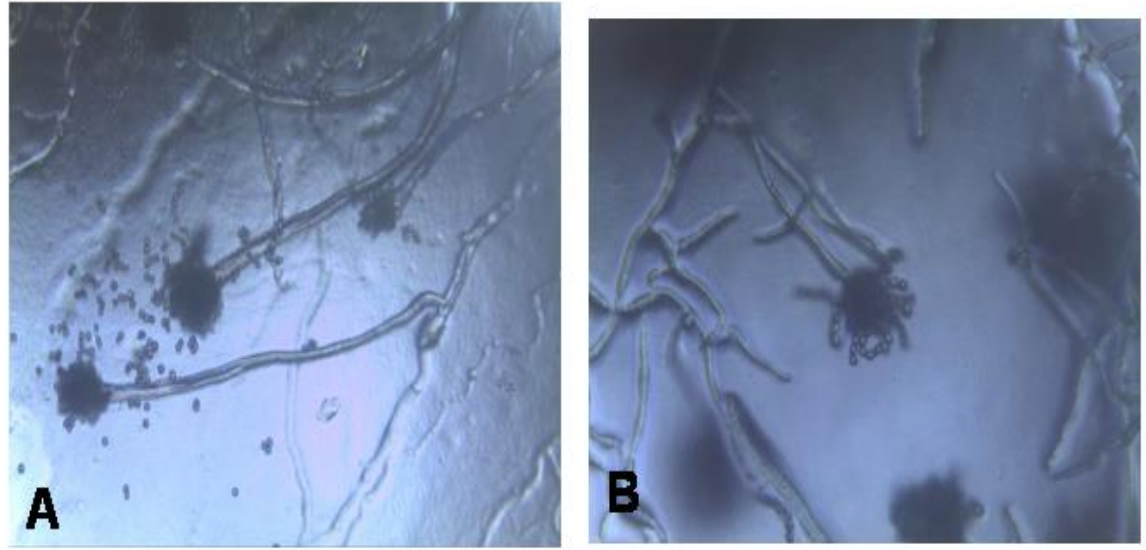

Fig 2. The morphological properties of the fungal isolates (A-Aspergills fumigatus SW1 and B-Aspergillus flavus SW2)

\subsubsection{The second instar larvae}

The second instar larvae inoculated with the Aspergillus fungus did not show any external disease symptoms at the beginning of the infection, but larvae became brown during the fasting period and failed to molt, and most of the larvae died after three days of inoculation (Fig 3 B).

\subsubsection{The third instar larvae}

After 72 hours of treatment with Aspergillus, larvae became slow in movement and lost their appetite, the end-abdominal area became fossilized and black in color and larvae died within few hours after the onset of symptoms. After 24 hours of death, Fungus propagules appeared on corpses (Fig $3 \mathbf{C}$ ). 

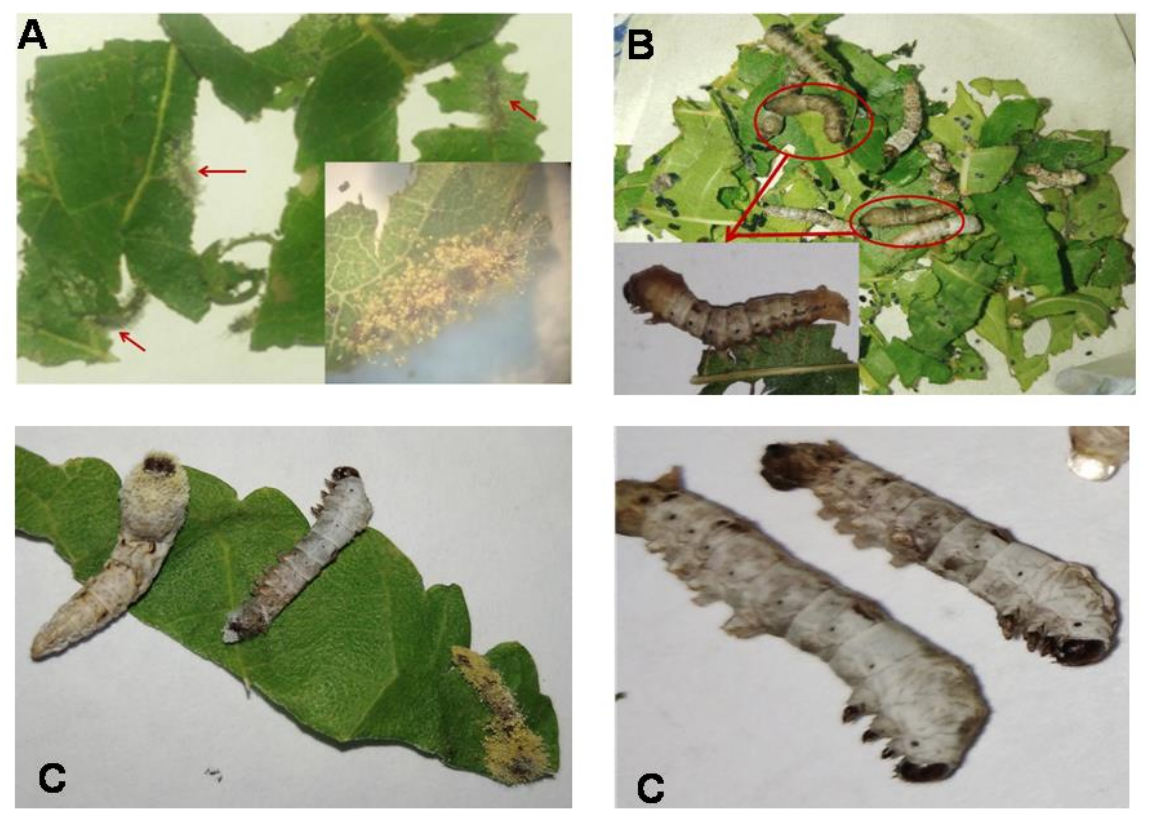

Fig 3. Symptoms of infection with Aspergillus spp. to mulberry silkworm:
A. The first instar larvae
B. The second instar larvae
C. The third instar larvae

\subsubsection{The fourth instar larvae}

Newly molted fourth instar silkworms treated with Aspergillus fungus did not show any symptoms at the beginning of the infection, but after four days of treatment, black spots were noticed at the anal area, as this area hardened, and larvae died within 24 hrs. (Fig 4A).

On the fifth day of treatment and in some larvae during the fasting period, a part of the hindgut was released out of the abdomen, and their color turned brown and then died (Fig 4B).

Some other larvae tried to molt but they died during molting. After death, Fungus propagules were noticed in the mouth, anus, or their whole bodies (Fig 4C). On the other hand, some larvae that have succeeded in molting and reached the fifth larval instar, showed black spots at the end of the abdomen in the anal area and charred in the parts of the mouth. Black spots surrounded by oily spots were also noticed in different places on the body. These larvae lost their appetite and died within two or three days. The infected larvae were hardened and after 24 hrs. of death, Fungus propagules grow in the affected areas (Fig 4D).

\subsubsection{The fifth instar larvae}

Fifth instar larvae treated with Aspergillus fungus, immediately after molting, had black spots on the fifth day of treatment on the head, end of the abdomen, abdominal legs, and the respiratory stomata. These larvae became slow in movement and lost their appetite and died within few days of the onset of symptoms, hardened and the affected areas had fungal propagules (Fig 5).

\subsubsection{The pupal stage}

When the larvae infected at the end of the fifth instar larvae, oily spots appeared on the larvae around the respiratory stomata or in the membrane between the rings. The size of these spots increased daily until the larvareached the stage of secretion of the cocoon where the larva completed the spinning of the cocoon (Fig 6). These cocoons were smaller in size or fragile compared to the uninfected pupae. 

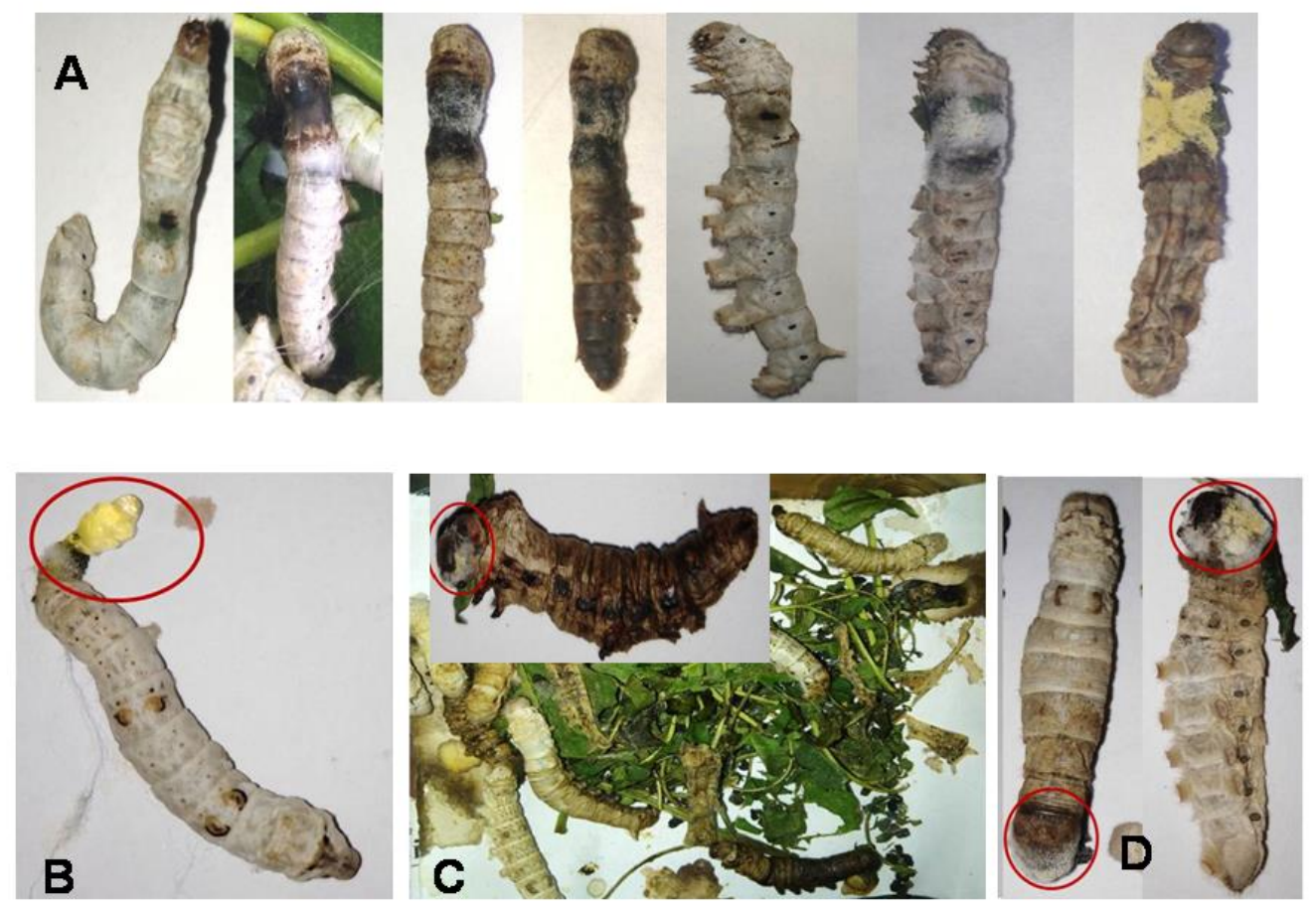

Fig 4. Symptoms of infection with Aspergillus spp. to mulberry silkworm (Fourth instar larvae)

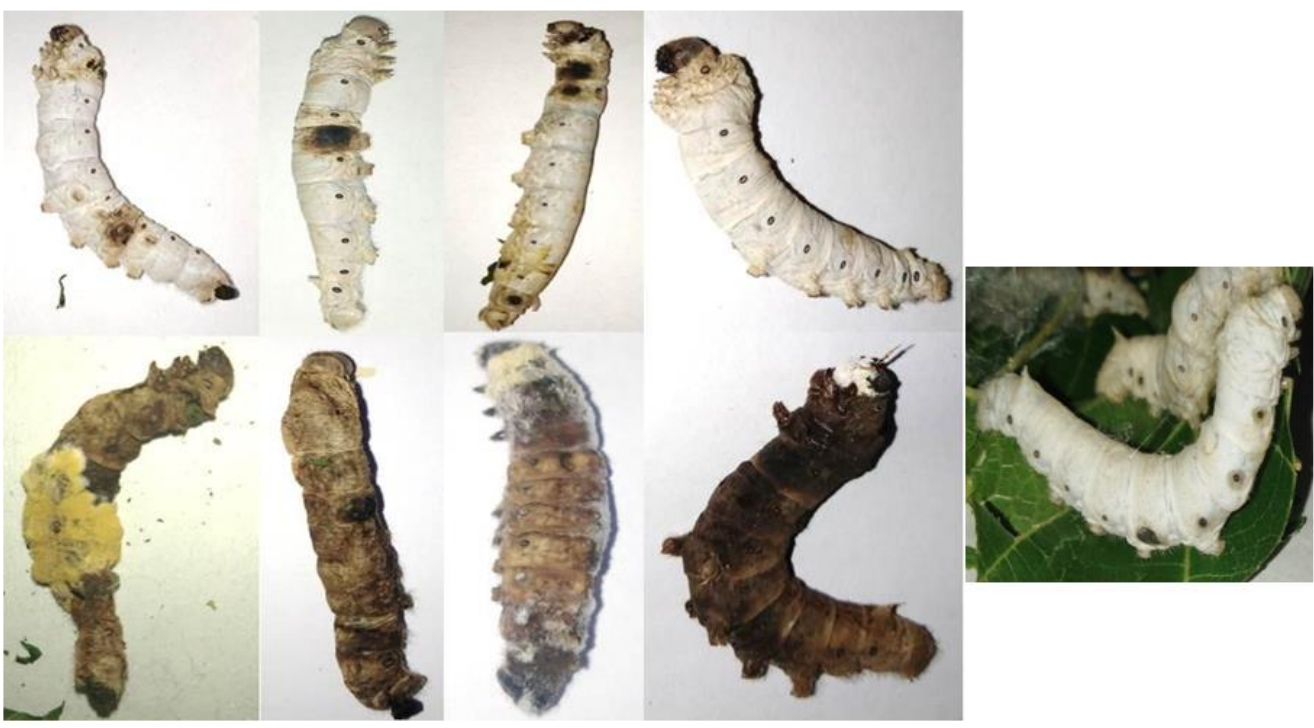

Fig 5. Symptoms of infection with Aspergillus spp. to mulberry silkworm (Fifth instar larvae) 


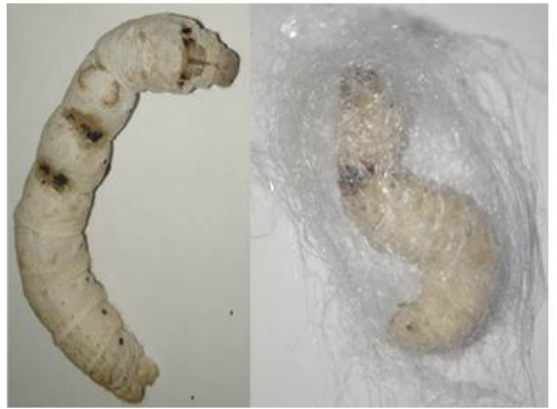

Fig 6. The infected larva can spin a cocoon

The larvae died in the pre-pupal stage and fungal propagules appeared in the places of infection or covered the whole body of the larva (Fig 7). When larvae reached the pupal stage, black spots appeared around the respiratory stomata. These pupae died and hardened, and the appearance of the fungal propagules in the areas of infection is noticed (Fig 8).

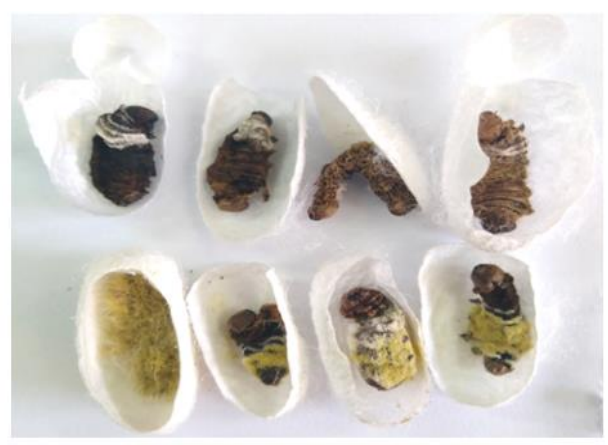

Fig 7. In the pre-pupal stage the fungus appear in the places of infection

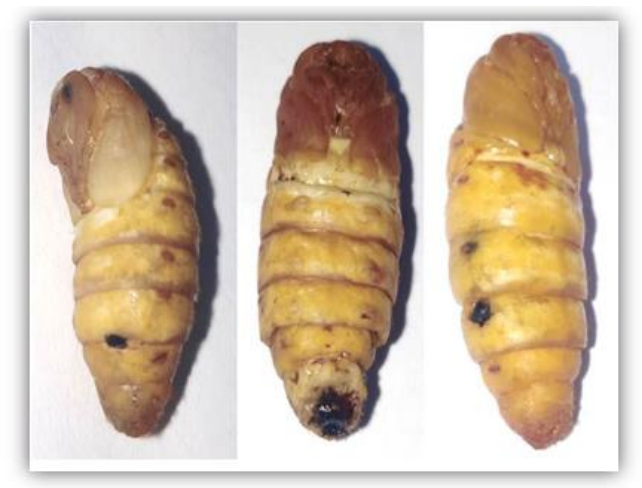

Fig 8. In the pupal stage black spots appear on pupa

\subsubsection{The adult stage}

Some infected pupae succeeded in reaching the adult stage, but these pupae either failed to get rid of the pupal skin or produced deformed moths with spots on the body and wings (Fig 9).

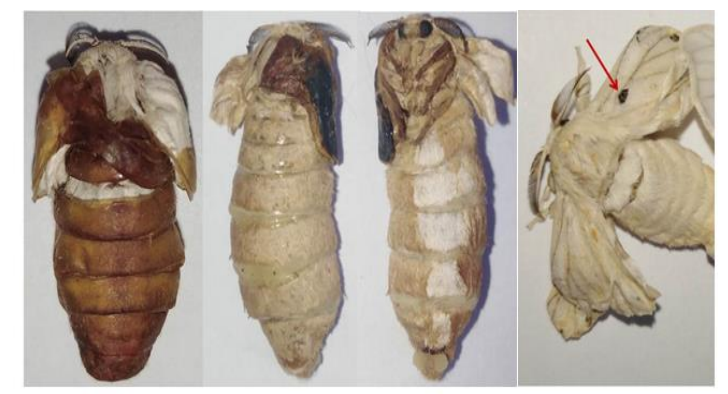

Fig 9. In the adult stage, black spot appeared on the body and some adults were deformed

3.3 Effect of treatments on controlling Aspergillus spp.

\subsubsection{Aspergillus fumigatus}

The mortality of inoculated larvae of mulberry silkworm with $A$. fumigatus was affected by different concentrations of the fungicide, Actamyl, salicylic acid, henna powder and propolis powder. In the larvae that inoculated with A. fumigatus without any treatment with fungicide, salicylic acid, henna powder and propolis powder, the mortality reached $100 \%$. Data in Table 1, show the effect of different concentrations of Actamyl on mortality and survival of larvae after 4 days of treatment with A. fumigatus after 1 and $12 \mathrm{hrs}$. The mortality decreased and reached $21.43 \%$. At the same time, the survival increased to 78.57 at $6 \%$ of Actamyl when the inoculated larvae were treated after $12 \mathrm{hrs}$.

On the other hand, data in Table 2, show the effect of salicylic acid with different concentrations on mortality and survival of mulberry silkworm larvae which inoculated with A. fumigatus. The low mortality $(20 \%)$ and high survival $(80 \%)$ occurred at $15 \%$ of salicylic acid in the larvae treated with 
A. fumigatus treated after $12 \mathrm{hrs}$. from inoculation. When different concentrations of propolis were used to control A. fumigatus it was found that lower concentrations did not affect mortality percentages significantly when inoculated larvae were treated after $1 \mathrm{hr}$. while mortality reached $66.66 \%$ and survival reached to $33.43 \%$ at $15 \%$ of propolis treatment. On the other hand, larvae inoculated with A. fumigatus with propolis at $15 \%$ treated $12 \mathrm{hrs}$. after inoculation, had low mortality $33.33 \%$ and high survival $66.67 \%$ (Table 3). Larvae of mulberry silkworm inoculated with A. fumigatus were affected by different concentrations of henna powder where larvae treated with the powder of henna at $15 \%$ after $12 \mathrm{hrs}$. of inoculation with A. fumigatus had $40 \%$ of mortality and $60 \%$ of survival (Table 4).

\subsubsection{Aspergillus flavus}

Larvae of mulberry silkworm inoculated with A. flavus were affected by different concentrations of some materials to control it via mortality and survival percentages calculated after 8 days from inoculation. Data in Tables 5 and 6, show that the mortality and survival percentages of larvae after inoculation with $A$. flavus and treated with Actamyl at $6 \%$ and salicylic acid at $15 \%$ after $12 \mathrm{hrs}$. from inoculation compared with infected control (inoculated larvae without fungicide and salicylic acid treatments) were $9.91 \%$ and 85.13 in fungicide and $16.66 \%$ and 72.74 , in salicylic acid treatment, respectively.

On the other hand, propolis at $15 \%$ affected the mortality and survival of inoculated larvae after $1 \mathrm{hr}$. more than after $12 \mathrm{hrs}$. where mortality was $20 \%$ and the survival was $67.27 \%$ compared with infected control (larvae inoculated with A. flavus without propolis treatment, (Table 7). The mortality and the survival percentages were the same at $15 \%$ of henna powder after 1 and $12 \mathrm{hrs}$.inspection of inoculated larvae, being $8.33 \%$ and $86.37 \%$, respectively (Table 8).

Fungal diseases are among the most dangerous diseases for the rearing of mulberry silkworms, which negatively affect the production of cocoons (Shobha et al 2016). A. fumigatus affect the silk gland in larvae and consequently the production of silk (Harinatha, 2017). The main reason for the appearance of fungal diseases is the high humidity and the failure to use appropriate methods to prevent the infection (Kawakami, 1982). Among the most famous fungal diseases are Aspergillosis diseases caused by Aspergillus spp. such as $A$. flavus, A. oryzae, A. tamarii, A. niger, A. ochraceus, A. sojae, A. fumigatus, A. nidulans, A. flavipes, A. clavatus, A. terreus, A. melleus, A. elegans, A. parasiticus (Govindan and Devaiah 1995, Kawakami 1995).

Recently, some chemicals, such as Bavistin fungicides, are used to control fungal diseases on the larvae (Singh et al 2002), in addition to the use of ciprofloxacin antibiotic against to flacherie disease (Mohanta et al 2015) and using natural materials. Saad et al (2019) used some plant extracts to control fungal diseases such as Ocimum basilicum leaves extracts and Nigella sativa seeds extract which positively affected weight and mortality of larvae and silk ratio. Singh et al (2002) used fungicides and natural plant products against the Aspergillosis diseases and found that salicylic acid, Bavistin fungicides, henna leaf powder and Mango bark powder were effective for controlling Aspergillus diseases in silkworm rearing. 

Silkworm Larvae Infected with Aspergillus spp.

Table 1. The mortality afterfour days in larvae of Bombyx mori infected by Aspergillusfumigatus treated with different concentrations of the fungicide, Actamyl

\begin{tabular}{|c|c|c|c|c|c|c|}
\hline \multirow{2}{*}{$\begin{array}{c}\text { Fungicide } \\
(\%)\end{array}$} & \multicolumn{3}{|c|}{1 hr. after inoculation } & \multicolumn{3}{c|}{12 hrs. after inoculation } \\
\cline { 2 - 7 } & mortality & $\begin{array}{c}\text { Survival } \\
(\%)\end{array}$ & $\begin{array}{c}\text { \% survival } \\
\text { increase } \\
\text { over inoculated } \\
\text { control }\end{array}$ & $\begin{array}{c}\% \\
\text { mortality }\end{array}$ & $\begin{array}{c}\text { Survival } \\
(\%)\end{array}$ & $\begin{array}{c}\text { \% survival } \\
\text { increase } \\
\text { over inoculated } \\
\text { control }\end{array}$ \\
\hline 2 & 66.66 & 33.34 & 33.34 & 69.23 & 30.77 & 30.77 \\
\hline 4 & 50.00 & 50.00 & 50.00 & 66.66 & 33.34 & 33.34 \\
\hline 6 & 33.33 & 66.67 & 66.67 & 21.43 & 78.57 & 78.57 \\
\hline $\begin{array}{c}\text { inoculated } \\
\text { control }\end{array}$ & 100 & 0.00 & -- & 100 & 0.00 & - \\
\hline
\end{tabular}

Table 2. The mortality after four days in larvae of Bombyx mori infected by Aspergillusfumigatus treated with different concentrations of salicylic acid

\begin{tabular}{|c|c|c|c|c|c|c|}
\hline \multirow{2}{*}{$\begin{array}{c}\text { Salicylic } \\
\text { acid (\%) }\end{array}$} & $\begin{array}{c}\% \\
\text { mortality }\end{array}$ & $\begin{array}{c}\text { Survival } \\
(\%)\end{array}$ & $\begin{array}{c}\text { \% survival } \\
\text { increase } \\
\text { over inoculated } \\
\text { control }\end{array}$ & $\begin{array}{c}\text { \% } \\
\text { mortality }\end{array}$ & $\begin{array}{c}\text { Survival } \\
(\%)\end{array}$ & $\begin{array}{c}\text { \% survival } \\
\text { Increase } \\
\text { over inoculated } \\
\text { control }\end{array}$ \\
\hline 5 & 66.66 & 33.34 & 33.34 & 33.33 & 66.67 & 66.67 \\
\hline 10 & 66.66 & 33.34 & 33.34 & 20.00 & 80.00 & 80.00 \\
\hline 15 & 53.33 & 46.67 & 46.67 & 20.00 & 80.00 & 80.00 \\
\hline $\begin{array}{c}\text { inoculated } \\
\text { control }\end{array}$ & 100 & 0.00 & -- & 100 & 0.00 & - \\
\hline
\end{tabular}

Table 3. The mortality after four days in larvae of Bombyx mori infected by Aspergillusfumigatus treated with different concentrations of the propolis

\begin{tabular}{|c|c|c|c|c|c|c|}
\hline \multirow{2}{*}{$\begin{array}{c}\text { Propolis } \\
(\%)\end{array}$} & \multicolumn{3}{|c|}{ 1 hr. after inoculation } & \multicolumn{3}{c|}{12 hrs. after inoculation } \\
\cline { 2 - 7 } & $\begin{array}{c}\% \\
\text { mortality }\end{array}$ & $\begin{array}{c}\text { Survival } \\
(\%)\end{array}$ & $\begin{array}{c}\text { \% survival } \\
\text { increase } \\
\text { over inoculated } \\
\text { control }\end{array}$ & $\begin{array}{c}\% \\
\text { mortality }\end{array}$ & $\begin{array}{c}\text { Survival } \\
(\%)\end{array}$ & $\begin{array}{c}\text { \% survival } \\
\text { increase } \\
\text { over inoculated } \\
\text { control }\end{array}$ \\
\hline 5 & 93.33 & 6.67 & 6.67 & 80.00 & 20.00 & 20.00 \\
\hline 10 & 86.66 & 13.34 & 13.34 & 53.33 & 46.67 & 46.67 \\
\hline 15 & 66.66 & 33.34 & 33.34 & 33.33 & 66.67 & 66.67 \\
\hline $\begin{array}{c}\text { inoculated } \\
\text { control }\end{array}$ & 100 & 0.00 & -- & 100 & 0.00 & - \\
\hline
\end{tabular}


Table 4. The mortality after four days in larvae of Bombyx mori infected by Aspergillus fumigatus and treated with different concentrations of the henna

\begin{tabular}{|c|c|c|c|c|c|c|}
\hline \multirow{2}{*}{$\begin{array}{c}\text { Henna } \\
\text { Powder } \\
(\%)\end{array}$} & \begin{tabular}{c}
$\%$ \\
\cline { 2 - 7 }
\end{tabular} & $\begin{array}{c}\text { Survival } \\
(\%)\end{array}$ & $\begin{array}{c}\text { \% survival } \\
\text { increase } \\
\text { over inoculated } \\
\text { control }\end{array}$ & $\begin{array}{c}\% \\
\text { mortality }\end{array}$ & $\begin{array}{c}\text { Survival } \\
(\%)\end{array}$ & $\begin{array}{c}\text { \% survival } \\
\text { increase } \\
\text { over inoculated } \\
\text { control }\end{array}$ \\
\hline 5 & 80.00 & 20.00 & 20.00 & 57.14 & 42.86 & 42.86 \\
\hline 10 & 53.33 & 46.67 & 46.67 & 53.33 & 46.67 & 46.67 \\
\hline 15 & 46.66 & 53.34 & 53.34 & 40.00 & 60.00 & 60.00 \\
\hline $\begin{array}{c}\text { inoculated } \\
\text { control }\end{array}$ & 100 & 0.00 & -- & 100 & 0.00 & - \\
\hline
\end{tabular}

Table 5. The mortality after eight days in larvae of Bombyx mori infected by Aspergillusflavus treated with different concentrations of the fungicide, Actamyl

\begin{tabular}{|c|c|c|c|c|c|c|}
\hline \multirow{2}{*}{$\begin{array}{c}\text { Fungicide } \\
(\%)\end{array}$} & \multicolumn{3}{|c|}{ 1 hr. after inoculation } & \multicolumn{3}{c|}{ 12 hrs. after inoculation } \\
\cline { 2 - 7 } & $\begin{array}{c}\text { \% } \\
\text { mortality }\end{array}$ & $\begin{array}{c}\text { Survival } \\
(\%)\end{array}$ & $\begin{array}{c}\text { \% survival } \\
\text { increase } \\
\text { over inoculated } \\
\text { control }\end{array}$ & $\begin{array}{c}\text { \% } \\
\text { mortality }\end{array}$ & $\begin{array}{c}\text { Survival } \\
(\%)\end{array}$ & $\begin{array}{c}\text { \% survival } \\
\text { increase } \\
\text { over inoculated } \\
\text { control }\end{array}$ \\
\hline 2 & 25.00 & 75.00 & 59.09 & 36.36 & 63.64 & 40.50 \\
\hline 4 & 14.29 & 85.71 & 76.62 & 16.66 & 83.34 & 72.74 \\
\hline 6 & 14.29 & 85.71 & 76.62 & 9.09 & 90.91 & 85.13 \\
\hline $\begin{array}{c}\text { inoculated } \\
\text { control }\end{array}$ & 61.11 & 38.89 & - & 61.11 & 38.89 & - \\
\hline
\end{tabular}

Table 6. The mortality after eight days in larvae of Bombyx mori infected by Aspergillus flavus treated with different concentrations of the salicylic acid

\begin{tabular}{|c|c|c|c|c|c|c|}
\hline \multirow{2}{*}{$\begin{array}{c}\text { Salicylic } \\
\text { acid (\%) }\end{array}$} & \multicolumn{3}{|c|}{$\mathbf{1}$ hr. after inoculation } & \multicolumn{3}{|c|}{12 hrs. after inoculation } \\
\cline { 2 - 7 } & mortality & $\begin{array}{c}\text { Survival } \\
(\%)\end{array}$ & $\begin{array}{c}\text { \% survival } \\
\text { increase } \\
\text { over inoculated } \\
\text { control }\end{array}$ & $\begin{array}{c}\text { \% } \\
\text { mortality }\end{array}$ & $\begin{array}{c}\text { Survival } \\
(\%)\end{array}$ & $\begin{array}{c}\text { \% survival } \\
\text { increase } \\
\text { over inoculated } \\
\text { control }\end{array}$ \\
\hline 5 & 50.00 & 50.00 & 18.18 & 42.66 & 57.34 & 30.19 \\
\hline 10 & 28.57 & 71.43 & 53.25 & 36.36 & 63.64 & 40.50 \\
\hline 15 & 20 & 80 & 67.27 & 16.66 & 83.34 & 72.74 \\
\hline $\begin{array}{c}\text { inoculated } \\
\text { control }\end{array}$ & 61.11 & 38.89 & - & 61.11 & 38.89 & - \\
\hline
\end{tabular}



Silkworm Larvae Infected with Aspergillus spp.

Table 7. The mortality after eight days in larvae of Bombyx mori infected by Aspergillus flavus treated with different concentrations of the propolis

\begin{tabular}{|c|c|c|c|c|c|c|}
\hline \multirow{2}{*}{$\begin{array}{c}\text { Propolis } \\
(\%)\end{array}$} & \begin{tabular}{c}
$\boldsymbol{\%}$ \\
\cline { 2 - 7 }
\end{tabular} & $\begin{array}{c}\text { Survival } \\
(\boldsymbol{\%})\end{array}$ & $\begin{array}{c}\text { \% survival } \\
\text { increase } \\
\text { over inoculated } \\
\text { control }\end{array}$ & $\begin{array}{c}\boldsymbol{\%} \\
\text { mortality }\end{array}$ & $\begin{array}{c}\text { Survival } \\
(\%)\end{array}$ & $\begin{array}{c}\text { \% survival } \\
\text { increase } \\
\text { over inoculated } \\
\text { control }\end{array}$ \\
\hline 5 & 54.54 & 45.46 & 10.75 & 42.85 & 57.15 & 29.88 \\
\hline 10 & 45.45 & 54.55 & 25.63 & 28.00 & 72.00 & 54.18 \\
\hline 15 & 20.00 & 80.00 & 67.27 & 25.00 & 75.00 & 59.09 \\
\hline $\begin{array}{c}\text { inoculated } \\
\text { control }\end{array}$ & 61.11 & 38.89 & - & 61.11 & 38.89 & - \\
\hline
\end{tabular}

Table 8. The mortality after eight days in larvae of Bombyx mori infected by Aspergillusflavus treated with different concentrations of the henna

\begin{tabular}{|c|c|c|c|c|c|c|}
\hline \multirow{2}{*}{$\begin{array}{c}\text { Henna } \\
\text { Powder } \\
(\%)\end{array}$} & \begin{tabular}{c}
$\boldsymbol{\%}$ \\
\cline { 2 - 7 }
\end{tabular} & $\begin{array}{c}\text { Survival } \\
(\boldsymbol{\%})\end{array}$ & $\begin{array}{c}\text { \% survival } \\
\text { increase } \\
\text { over inoculated } \\
\text { control }\end{array}$ & $\begin{array}{c}\boldsymbol{\%} \\
\text { mortality }\end{array}$ & $\begin{array}{c}\text { Survival } \\
(\%)\end{array}$ & $\begin{array}{c}\text { \% survival } \\
\text { increase } \\
\text { over inoculated } \\
\text { control }\end{array}$ \\
\hline 5 & 25.00 & 75.00 & 59.09 & 18.18 & 81.82 & 70.25 \\
\hline 10 & 16.66 & 83.34 & 72.74 & 16.66 & 83.34 & 72.74 \\
\hline 15 & 8.33 & 91.67 & 86.37 & 8.33 & 91.67 & 86.37 \\
\hline $\begin{array}{c}\text { inoculated } \\
\text { control }\end{array}$ & 61.11 & 38.89 & - & 61.11 & 38.89 & - \\
\hline
\end{tabular}

\section{Conclusion}

Two species of fungi that infect mulberry silkworms have been isolated and identified: Aspergillus fumigatus and Aspergillus flavus. Fungicide (Actamyl), salicylic acid, henna powder and propolis powder were used in different concentrations on the mulberry silkworms that were inoculated after an hour and another after 12 hours, and the best period for controlling fungi was 12 hours af ter inoculated the larvae with fungi. The fungicides are considered the most effective in controlling fungal diseases, followed by salicylic acid, henna powder and finally propolis powder.

\section{Acknowledgment}

Authors are grateful to Dr. Medhat Kamel, Prof. at the Botanical Clinic, Department of Plant Diseases, Fac. Agric., Ain Shams Univ., Cairo, Egypt, for the great support and help in fungal isolates identification used in this study.

\section{References}

Barnett HL, Hunter BB (1998) The illustrated genera of imperfect fungi. In: The American Phytopathological Society, fourth ed. Macmillian, New York, USA, p. 218.

Cantwell GE (1970) Standard methods for counting Nosema spores. American Bee Journal 110, 222-223.

Difco Manual (1998). "Dehydrated Culture Media and Reagents for Microbiology". Sparks, Maryland 21152, USA, Difco Laboratories, Division of Becton Dickinson and Company, $11^{\text {th }}$ Edition.

Doreswamy CR, Govindan R, Devaiah MC, Muniswamappa MV (2004) Deterioration of cocoon traits of silkworm, Bombyx mori L. by the synergistic infection with late larval flacherie pathogens. Karnataka J Agric Sci 17, 345348. 
Govindan R, Devaiah MC (1995) Aspergillosis of silkworm. Silkworm Pathology Techinical, Dept of Seri UAS Bangalore, India, 68p.

Harinatha RA (2017) Effect of Aspergillus fumigatus infection on the silk gland of bombyx mori L. Int J Recent Sci Res 8, 21731-21733. DOI:

http://dx.doi.org/10.24327/ijrsr.2017.0811.11 29

Humber AR (2005) Entomopathogenic fungal identification. USDA-ARS Plant Protection Research Unit, US Plant, Soil and Nutrition Laboratory, Itheca, New York, 1-32 pp.

Johny S, Kyei-Poku G, GauthierD, van Frankenhuyzen K, Krell PJ (2012) Characterization and virulence of Beauveria spp. recovered from emerald ash borer in southwestern Ontario, Canada. Journal of Invertebrate Pathology 111, 41-49.

Kawakami K (1982) Causal pathogens of Aspergillus disease of silkworm and its control. JARQ. 15,185-190.

Kawakami K (1995) Susceptibility of several varieties of the silkworm, Bombyx mori L. to Aspergillus disease and germination of fungus spores in larval haemolymph. J Seric Sci Jpn 44, 39-44.

Khyade VB, Tyagi BK (2017) Detection of Grasserie Virus, Bm NPV in the Fifth Instar Larvae of Silkworm, Bombyx mori (L) (Race: PM x CSR2) Through Polymerase Chain Reaction. Int J Curr Microbiol App Sci 6, 13-23.

Krishnaswami S (1983) Evolution of new bivoltine race for traditionally multivoltine areas of south India. Indian Silk, 22, 3-11.

Mohanta MK, Saha AK, Saleh DKMA, Islam MS, Mannan KSB, Fakruddin M (2015) Characterization of Klebsiella granulomatis pathogenic to silkworm, Bombyx mori L. 3 Biotech 5, 577-583. DOI 10.1007/s13205-0140255-4.

Nour FW (2009) Nutritional efficiency of certain compounds on silk production and fecundity of mulberry silkworm. M. Sc. Thesis, Fac of Agric., Ain Shams Univ 191 pp.

Saad MSI, Elyamani EMY, Helaly WMM (2019) Controlling of bacterial and fungal diseases that contaminating mulberry silkworm, Bombyx mori by using some plant extracts. Bulletin of the National Research Centre 43, 172. https://doi.org/10.1186/s42269-0190218-3.

Sharma A, Sharma P, Thakur J, Murali S, Bali K (2020) Viral diseases of Mulberry Silkworm, Bombyx mori L. - A Review. Journal of Pharmacognosy and Phytochemistry 9, 415423.

Shobha R, Reddy A, Venkatappa B (2016) Catalase activity in haemolymph of silkworm (Bombyx mori L.) following fungal infection. $J$ Biol and Nature 5, 148-153.

Simmons Z, Bremer BA, Robbins RA, Walsh SM, Fischer S (2000) Quality of life in ALS depends on factors other than strength and physical function. Neurology 55, 388-392.

Singh GP, Sharma SD, Selvakumar T, Nataraju B, Data RK (2002) Screening of fungicides and natural plant products and their efficacy on control of Aspergillosis in silkworm, Bombyx mori L. Int J Indust Entomol 4, 5-11.

Veeranna G (1999) Integrated silkworm disease management: China Vs India. Indian Silk 38, 27-28.

Yadav S, Singh H, Kumar A, Singh H (2014) Isolation and identification of bacteria responsible for bacterial flacherie disease in mulberry silkworm (Bombyxmori Lin.) under laboratory condition. Ann Entomol 34, 1-5. 